\title{
KOMPETISI DAN KOLABORASI: STRATEGI HOTEL-HOTEL PEGUNUNGAN (BERGHOTEL) DI GARUT PADA MASA KOLONIAL (1890-1942)
}

\author{
COMPETITION AND COLLABORATION: THE STRATEGY OF MOUNTAIN \\ HOTELS (BERGOTEL) IN GARUT IN THE COLONIAL PERIOD (1890-1942) \\ Irfal Mujaffar \\ Departemen Sejarah Fakultas Ilmu Pengetahuan Budaya Universitas Indonesia \\ Kampus UI Depok Jawa Barat 16424 \\ irfalmujaffar2711@gmail.com
}

DOI: $10.36424 / j p s b . v 7 i 2.255$

Naskah Diterima: 31 Maret 2021 Naskah Direvisi: 13 September 2021 Naskah Disetujui: 13 September 2021

\begin{abstract}
Abstrak
Popularitas Garut sebagai tujuan utama pariwisata pada periode akhir kolonial menarik minat para pelaku usaha akomodasi untuk merintis usaha-usaha mereka di kawasan ini. Semenjak itu Garut berkembang menjadi salah satu episentrum persebaran hotel-hotel pegunungan (berghotel) yang menawarkan akomodasi bagi para wisatawan. Kondisi tersebut memicu terjadinya persaingan di antara mereka. Artikel ini berfokus pada strategi hotel-hotel pegunungan di Garut dalam menjaring lalu lintas wisatawan. Sumber yang digunakan adalah buku-buku, surat kabar, majalah, buku panduan wisata, dan catatan perjalanan sezaman. Dengan menggunakan metode sejarah, hasil dari kajian ini menunjukan bahwa dalam menyiasati tekanan persaingan untuk mendapatkan wisatawan, hotel-hotel pegunungan di Garut menempuh berbagai strategi melalui pengembangan inovasi dan bentuk-bentuk kolaborasi.
\end{abstract}

Kata Kunci: hotel pegunungan, akomodasi pariwisata kolonial, Garut.

\section{Abstract}

Garut's popularity as a tourist destination in the late colonial period has caused many accommodation entrepreneurs to set up business within the city. From that moment, Garut has become one of the centers for the existence of mountain hotels (berghotels) for tourists. This article will be focused on the strategy of mountain hotels in Garut to attract tourists. The sources are used from books, newspapers, magazines, the guide books of tourism as well as travelogues from that time. By using the historical method, the results shows that mountain hotels in Garut develop a mixture of competing strategies to attract tourists by innovating and collaborating.

Keywords: mountain hotel, colonial tourism accommodation, Garut 


\section{PENDAHULUAN}

Di antara dampak dari adanya praktik pariwisata di Hindia Belanda adalah berkembangnya bidang usaha jasa akomodasi, khususnya hotel. Ramainya lalu lintas wisatawan yang mengarus dalam setengah abad terakhir kekuasaan kolonial tampaknya telah menarik minat para pelaku usaha perhotelan untuk merintis usaha-usaha mereka di negeri yang dikenal para pelancong sebagai The Garden of the East ini. Hotel-hotel yang mereka dirikan tersebardi lokasi-lokasi yang menjadi pusat kegiatan pariwisata, terutama di daerah-daerah pegunungan.

M.A.J. Kelling (1929) mengatakan ada dua kategori hotel yang dikenal secara umum di Hindia Belanda, yaitu staadshotel (hotel kota) dan berghotel (hotel pegunungan). Keberadaan staadshotel terkait erat dengan lalu lintas orang asing. Biasanya lokasi staadhotel dibangun di pusat-pusat kota dan daerah sekitar pelabuhan atau dikenal juga dengan istilah staadherberg (penginapan kota). Akomodasi jenis ini mulanya disediakan untuk para pedagang yang datang dari negeri jauh/asing serta para pelancong dari beragam latar kepentingan. Dengan demikian, sirkulasi pengunjung staadshotel cenderung intens, namun dengan jangka waktu tinggal yang relatif singkat.

Sedangkan keberadaan berghotel terkait dengan adanya kegiatan pariwisata dan pengembangan sanatorium di daerah pegunungan. Target konsumennya menyasar wisatawan dan pencari kesehatan. Itu sebabnya sirkulasi pengunjung berghotel tidak seintens staadhotel. Kesibukan biasanya terjadi dalam waktu-waktu tertentu saja, seperti akhir pekan atau musim liburan. Walau begitu, para pengunjung cenderung menghabiskan waktu tinggal mereka lebih lama (Kelling, 1929: 744-745).

Garut merupakan salah satu episentrum persebaran berghotel di Hindia Belanda. Tonggak awal perkembangan hotel-hotel di Garut dimulaisekitar tahun 1890-an seiring dengan dibukanya kawasan ini sebagai stasiun perbukitan dan sanatorium (De Witt, 1898: 242; Ponder, 1934: 189, 242). Geliat investasi pada sektor ini makin bergairah memasuki dekade kedua abad ke-20 ketika Garut mulai terhubung dengan jaringan pariwisata internasional. Ditandai dengan berdirinya sejumlah hotel baru yang dilengkapi fasilitas modern dan dikelola secara lebih profesional (Tourism in Netherland India, 1934). 
Menjamurnya hotel di Garut telah memicu terjadinya intensifikasi persaingan di antara para pelaku usahasektor ini. Pola persaingan yang terbentuk mengarah pada segmentasi pasar yang spesifik, yakni wisatawan (dan pencari kesehatan). Kondisi tersebut tampaknya menjadi konsekuensi yang mesti dihadapi para pemilik hotel di daerah-daerah pedalaman seperti Garut waktu itu, yang mana sumber utama pemasukan sangat bergantung pada lalu lintas wisatawan. Artinya, semakin ramai wisatawan yang datang maka makin besar pula kesempatan mereka memperoleh keuntungan.

Artikel ini membahas strategi hotel-hotel pegunungan (berghotel) di Garut dalam menjaring lalu lintas wisatawan pada periode akhir kolonial. Menurut Shaw dan Williams (2004: 83-85) pada dasarnya berbagai strategi yang diadopsi oleh para pelaku usaha akomodasi wisata bertujuan untuk meningkatkan kemampuan perusahaan agar mendapatkan nilai lebih atau keuntungan dari memproduksi jasa dan pengalaman pariwisata. Maka dari itu ada dua aspek penting yang perlu diperhatikan. Pertama, kemampuan hotel-hotel tersebut dalam menyiasati tekanan persaingan. Bukan hanya dari segi persaingan harga, melainkan yang terpenting adalah bagaimana mereka mampu mengubah paradigma persaingan melalui inovasi dalam hal teknologi, produk, proses, pengetahuan, dan lain sebagainya. Kedua adalah masalah perluasan jejaring. Ini berkaitan dengan sejauh mana hotel-hotel tersebut mampu melebarkan jejaring melalu berbagai bentuk kolaborasi dan aliansi.

Studi tentang akomodasi pariwisata kolonial di Hindia Belanda sudah pernah ditulis oleh sejumlah peneliti. Achmad Sunjayadi (2007, 2017, 2019) pernah membahas masalah ini dengan menitikberatkan pada aspek perkembangannya secara umum. Dalam tulisannya yang lain, Sunjayadi (2018) juga membahas peran pelayan pribumi di hotelhotel, seperti jongos, babu, dan mandor. Namun, kajian-kajian tersebut tidak mengkhususkan pembahasannya pada permasalahan berghotel yang notabene memiliki karaktersitik berbeda dari kebanyakan hotel di kota besar, baik secara visi maupun dari segi pengelolaannya.

Hotel pegunungan menjadi isu yang turut diangkat oleh J.E. Specer dan W.L. Thomas (1948) di dalam studinya tentang stasiun perbukitan (hill station) di negaranegara Asia kolonial. Studi ini mengaitkan keberadaan hotel pegunungan dengan 
fenomena kemunculan stasiun-stasiun perbukitan yang dikembangkan orang-orang Belanda di Hindia pada abad ke-19. Berangkat dari studi tersebut, William A. Whitington (1961) menulis laporan tentang kondisi terbaru sejumlah stasiun perbukitan di Indonesia pascakemerdekaan, termasuk juga mengulas sarana akomodasinya. Meskipun kedua studi ini menyinggung soal hotel pegunungan, namun baik Spencer maupun Whitington masih melihat institusi tersebut sebatas fasilitas pelengkap alih-alih mempersepsikannya sebagai sebuah entitas yang turut berkepentingan. Disinyalir itu karena keduanya belum mengeksplorasi signifikansi hubungan hotel-hotel pegunungan dengan praktik pariwisata di stasiun perbukitan.

Upaya untuk menguraikan hubungan antara sektor akomodasi dan praktik pariwisata kolonial di daerah pegunungan dilakukan oleh Andi Arismunandar (2020) dengan melihat apa yang terjadi di Keresidenan Priangan. Sama seperti studi terdahulu lainnya, secara keseluruhan kajian ini lebih banyak membahas aspek perkembangannya. Begitu pula dengan apa yang ditulis oleh Sulaeman Anggapradja (1984) dan Kunto Sofianto (1997) yang mengaitkan pertumbuhan hotel-hotel di Garut era kolonial dengan praktik pariwisata yang berkembang di sana. Kajian-kajian tersebut belum memperlihatkan adanya suatu tinjauan yang mengarah pada pola persaingan. Bagaimanapun, upaya peningkatan kualitas pelayanan dan fasilitas yang dilakukan para pemilik hotel bukan semata-mata ditujukan untuk memuaskan para pengunjung sebagaimana yang disampaikan oleh ketiga kajian tersebut, tetapi juga hal itu mesti dipahami sebagai bagian dari strategi dalam merespon tekanan persaingan.

Dari beberapa kajian yang telah disebutkan, dapat disimpulkan sejauh ini sektor akomodasi cenderung hanya dipersepsikan sebagai unsur pendukungpariwisata kolonial. Dengan kata lain, hadir sebatas menjadi sarana untuk memfasilitasi kebutuhan para wisatawan. Sektor akomodasi, khususnya hotel belum dilihat sebagai sebuah entitas yang juga ikut berkepentingan di dalam mata rantai praktik pariwisata yang berlangsung. Padahal akomodasi adalah sub-sektor terbesar dan paling banyak ditemukan dalam ekonomi pariwisata (Cooper, 1998: 313).

Maka dari itu, studi ini berusaha mendudukkan perkara tersebut sebagai isu utama melalui tinjauan terhadap strategi hotel-hotel pegunungan (berghotel) di Garut 
dalam menjaring lalu lintas wisatawan pada periode akhir kolonial. Ruang lingkup pembahasan akan difokuskan pada dua aspek dengan bertolak dari apa yang ditawarkan Shaw dan Willams (2004) tentang strategi perusahaan-perusahan pariwisata. Mula-mula tinjauan diarahkan terhadap kemampuan hotel-hotel tersebut dalam menyiasati tekanan persaingan (kompetisi). Selanjutnya adalah sejauh mana mereka mampu melebarkan jejaring melalui bentuk-bentuk kolaborasi dan aliansi.

\section{METODE PENELITIAN}

Studi ini menggunakan metode sejarah yang terdiri dari heuristik, kritik (verifikasi), interpretasi, dan historiografi (Gottschalk, 2008: 42; Sjamsuddin, 2012: 74). Perkembangan hotel-hotel pegunungan di Garut berjalan paralel dengan kegiatan pariwisata yang berlangsung di kawasan ini pada periode akhir kekuasaan kolonial. Maka dari itu, proses heuristik difokuskan pada sumber-sumber yang berkaitan dengan praktik pariwisata kolonial, seperti buku panduan, catatan perjalanan, arsip, majalah pariwisata, dan surat kabar.

Buku panduan berisi informasi seputar objek wisata serta fasilitas-fasilitas penunjang yang dapat diakses oleh para wisatawan, termasuk informasi mengenai sarana akomodasi di tempat tujuan beserta tarifnya. Contoh buku panduan yang digunakan, seperti yang ditulis Marius Buys (1891), VTV (1910, 1913), Doorman\& Nieuwenkamp (1898), dan Dyck, (1922). Lalu digunakan juga catatan perjalanan para wisatawan yang pernah mengunjungi Garut, seperti Maurik (1897), Scidmore (1898), Kloben (1899), Miller (1908), Walcott (1914), McMillan (1914), dan Couperus (1923). Catatan-catatan tersebut sangat berguna untuk membantu memberikan gambaran terkait pelayanan di hotel-hotel yang ditempati turis melalui testimoni mereka. Selain dari catatan perjalanan, testimoni juga bisa kita lihat dari arsip-arsip korespondesi antara wisatawan dengan VTV yang terhimpun dalam Algemene Secretarie (1891-1942).

Kemudian digunakan juga majalah dan surat kabar yang sering dimanfaatkan sebagai media promosi oleh hotel-hotel di Hindia. Dari sana kita bisa melihat keunggulan apa saja yang ditawarkan oleh hotel-hotel tersebut. Contoh majalah yang digunakan, antara lain The Tourist Guide and Garoet Express (1922-1923), Tourism in 
Netherland India(1932, 1934), dan Het Hotelblad (1937-1938). Sumber-sumber tersebut diperoleh di Perpustakaan Nasional RI, Arsip Nasional RI, Perpustakaan UI, serta situs-situs internet, seperti delpher.nl, archive.org, digital.library.cornell.edu, dan digitalcollections.universiteitleiden.nl.

\section{PEMBAHASAN}

\section{Perkembangan Hotel-Hotel Pegunungan (Berghotel) di Garut}

Keberadaan hotel-hotel pegunungan (berghotel) di Hindia merupakan suatu fenomena yang terkait dengan munculnya stasiun-stasiun perbukitan yang dikembangkan oleh orang-orang Belanda pada abad ke-19. Resor-resor semacam ini banyak dijumpai di negeri-negeri koloni Eropa yang beriklim tropis, terutama di Asia Selatan dan Asia Tenggara. Stasiun perbukitan biasanya dibangun di daerah-daerah pegunungan yang berhawa sejuk dan berpanorama indah untuk dimanfaatkan sebagai tempat peristirahatan (retret) dari cuaca panas berkepanjangan dan pemulihan kesehatan (Jafari, 2000: 277).

Masalah perbedaan iklim rupanya telah menjadi tantangan terberat yang dihadapi orang-orang kulit putih (Barat) sejak dua abad pertama kontak mereka dengan dunia timur. Tak ayal udara yang dirasa sangat panas dan lembab membuat mereka sering menderita dan mudah terserang penyakit. Untuk mengatasi masalah tersebut, mereka lalu mencari tempat-tempat berudara sejuk di daerah pegunungan yang suhunya dirasa sebanding dengan iklim di negara asal. Efek penyembuhan yang dihasilkan dari tinggal di dataran tinggi sudah dirasakan oleh orang-orang Inggris di India ketika mereka mendirikan markas-markas detasemen militer di sekitar pegunungan Himalaya pada 1820. Semenjak itu, mereka mulai rutin mengunjungi daerah-daerah pegunungan untuk memulihkan kesehatan (sanatorium) atau sekadar mengisi waktu luang (Spencer dan Thomas, 1948: 637-641).

Ketidaknyamanan akibat tinggal di negeri koloni yang beriklim tropis ternyata dirasakan pula oleh orang-orang Belanda di Hindia. Kondisi tersebut mendorong mereka untuk membangun stasiun-stasiun perbukitannya sendiri (De Witt, 1898: 242243). Proses awal pencarian lokasi untuk stasiun perbukitan diperkirakan sudah dimulai 
sejak awal abad ke-19 bersamaan dengan perluasan kendali militer Belanda ke daerahdaerah dataran tinggi di pedalaman Jawa. Mula-mula mereka mendirikan garnisungarnisun militer di sana yang juga dimanfaatkan sebagai sanatorium untuk para prajurit yang sakit (Spencer dan Thomas, 1948: 640). Menjelang akhir abad ke-19, tempattempat tersebut kemudian makin sering dikunjungi oleh semua lapisan kelas sosial Belanda untuk memalingkan diri sejenak dari panasnya udara perkotaan dan memulihkan kesehatan (Meulendijks, 2017: 28).

Spencer dan Thomas mengidentifikasi 23 daerah pegunungan di Hindia yang dikembangkan sebagai stasiun perbukitan selama masa kolonial. Daerah-daerah tersebut tersebar di tiga pulau yang berbeda: 18 titik di Pulau Jawa; 3 titik di Sumatera; dan 2 titik di Celebes. ${ }^{1}$ Dari jumlah tersebut, tiga di antaranya adalah stasiun perbukitan utama yang paling popular di kalangan parawisatawan, yaitu Tosari di Jawa Timur (6.000 kaki), Garut (2.300 kaki), dan Sindanglaya (3.500 kaki) di Jawa Barat (1948: 645).

Proses awal pengembangan Garut sebagai stasiun perbukitan diperkirakan mulai berlangsung sekitar tahun 1890-an seiring dengan penguatan kontrol keamanan dan perbaikan infrastruktur di Keresidenan Priangan. Pada saat itu kawasan Priangan dianggap sudah relatif aman berkat realisasi Preanger Reorganisatie "Reorganisasi Priangan" 1871, yang salah satu tujuannya adalah untuk memelihara keamanan dan kesehatan penduduk (Gelder, 1899: 49). Pada saat yang sama, liberalisasi ekonomi yang diberlakukan pemerintah menyebabkan daerah Priangan dibanjiri investasi swasta. Perkebuan-perkebunan teh dan kina milik swasta mulai dibuka di Garut pada 1880-an, (Anggapradja, 1984: 146).Guna menunjang pendistribusian hasil perkebunan mereka, pemerintah membangun sejumlah infrastruktur, terutama jaringan jalan raya dan jalur kereta (Furnivall, 2009: 188). Pada 1889, jalur kereta apimenuju Garut yang dibangun oleh Staatsspoorwegenresmi beroperasi. Semenjak itulGarut mulai terhubung dengan daerah lain dan makin mudah diakses (Mulyana, 2005: 128).

\footnotetext{
${ }^{1}$ Hindia Belanda menempati urutan kedua dengan stasiun perbukitan terbanyak di Asiadi bawah India yang memiliki 46 titik. Dari 23 titik stasiun perbukitan di Hindia itu tersebar di tiga pulau berbeda, antara lain: di Jawa ada Sempol, Tosari, Nongkojajar, Lawang, Malang, Prigen, Tretes, Songgoriti, Salatiga, Unggaran, Merbabu, Wonosobo, Kuningan, Garut, Bandung, Sindanglaya, Sukabumi, dan Buitenzorg; lalu di Sumatra ada Fort de Kock/Bukittinggi, Prapat, dan Bandar Baru; sedangkan di Celebes adalah Rurukan dan Tondano.
} 
Garut yang semula sepi dan cenderung dihindari, berubah menjadi kawasan yang ramai. Banyak pemukim Eropa di Hindia memanfaatkan waktu luang mereka dengan pergi ke Garut. Mereka menyukai tempat ini karena udaranya yang sejuk dan bersih sangat cocok untuk penyegaran diri dari cuaca panas perkotaan yang melelahkan serta baik untuk pemulihan kesehatan (Oemar, 1896; Miller, 1908: 161).

Bersamaan dengan itu sarana akomodasi berupa hotel dan jenis-jenis penginapan lainnya mulai banyak didirikan untuk memfasilitasi kebutuhan para pengunjung. Selain melayani penginapan, umumnya hotel-hotel di Garut juga menerima tamu-tamu yang sedang menjalani proses pemulihan. Dengan kata lain, berfungsi menjadi semacam rumah peristirahatan untuk para pencari kesehatan atau dikenal juga dengan istilah sanatorium (De Witt, 1898: 243; Maurik, 1897: 194; Scidmore, 1898: 312).

Perkembangan hotel pegunungan di Garut terbagi dalam dua pembabakan waktu, yaitu periode 1890-1907 dan periode 1908-1942. Keberadaan hotel-hotel pada periode pertama (1890-1907) erat kaitannya dengan stasiun perbukitan dan kegiatan pariwisata domestik. Ditandai dengan berdirinya hotel-hotel yang beradadi bawa pengawasan keluarga. Ciri khas dari hotel jenis ini adalah gemeenschappelijketafel 'meja bersama'. Maksud dari 'meja bersama' yaitu adanya keakraban dan kebersamaan antara pemilik atau pengelola hotel dengan tamu-tamunya. Pemilik hotel kerap berperan sebagai "ibu", "ayah", atau "bibi" bagi para tamunya (Kelling, 1929: 740). Biasanya bangunan yang kemudian berfungsi sebagai hotel awalnya merupakan rumah atau tempat tinggal pribadi yang menyewakan kamar-kamar atau paviliunnya. Itu sebabnya nama-nama hotel keuargakerap menggunakan nama pemiliknya (Sunjayadi, 2018: 153).

Contoh hotel keluarga di Garut adalah Hotel van Horck yang berlokasi di Station Road, sekitar 2-3 menit berjalan kaki dari stasiun Garut. ${ }^{2}$ Usaha akomodasimilik keluarga Horck itu mulai beroperasi tahun 1890, sekaligus menjadi hotel pertama yang berdiri di Garut. ${ }^{3}$ Bangunan hotel ini bertipe paviliun yang terdiri dari 30 kamar dan 1 rumah (disewakan)(Doorman dan Nieuwenkamp, 1898: 31). Hotel keluarga lainnya

${ }^{2}$ Lokasi Hotel van Horck sekarang berada sekitar komplek Kodim dan BNI Kota Garut sekarang di Jl. Veteran (Anggadipradja, 1984:159).

${ }^{3}$ Berita tentang pembukaan Hotel van Horck dimuat dalam surat kabar Bataviaasch Nieuwsblad, 12 Agustus 1890. 
adalah Hotel van Vogel yang berlokasi di dekat Alun-alun. Diperkirakan hotel ini mulai beroperasi antara tahun 1890-1891. ${ }^{4}$ Berbeda dari Horck, tipe penginapan Vogellebih menyerupai wisma. Hotel ini terkenal dengan kuda-kuda tunggangannya. Kuda-kuda tersebut kerap dimanfaatkan para tamunya untuk mencapai objek-objek wisata di Garut (Buys, 1891: 144).

Pada tahun 1897, istri seorang mendiang dokter di Garut membuka sebuah penginapan yang terdiri dari 14 kamar di bekas tempat praktik suaminya. Ia menamai penginapannya Hotel Rupert yang diambil dari nama mendiang suaminya. Lokasinya berada tepat di seberang Hotel van Horck. Selain menyediakan akomodasi, Hotel Rupert juga menerima kunjungan orang-orang yang sekadar datang untuk menjalani terapi kesehatan. Hotel ini memiliki ruang terapi uap dan bak rendam air panas yang dibuka untuk umum (Doorman dan Nieuwenkamp, 1898: 33). Fasilitas tersebut sebetulnya sudah ada sejak bangunan hotel ini masih berfungsi sebagai klinik. Dalam jurnal perjalanannya di Garut, Raja Siam dilaporkan beberapa kali menyempatkan waktunya untuk mandi di klinik tersebut.

"11 Juni 1896: Mandi di klinik seorang dokter yang terletak di seberang hotel (van Horck). Tiap kamar dilengkapi meja untuk berbaring yang dilindungi penutup seperti tenda. Pemanas air ditempatkan di bagian luar kamar-kamar sehingga dapat mengalirkan air panas untuk sauna atau pijat. Kamar mandi dilengkapi shower untuk air panas dan dingin"'(Katam \& Affandhi, 2012: 568).

Layaknya sebuah hotel keluarga yang banyak dijumpai di berbagai daerah di Hindia, hotel-hotel di Garut pada periode pertama juga identik dengan suasana kebersamaan dan keakrabannya. Justus van Maurik, seorang wisatawan asal Belanda membagikan kesannya selama ia tinggal di Hotel van Horck. Ia memuji cara pemilik hotel yang selalu memperlakukan para tamunya dengan sangat akrab.

"Ny. van Horck adalah sosok ibu yang baik bagi para tamunya. Ia tampak selalu tersenyum, murah hati, dan sangat ramah. Senyumannya bisa menularkan energi positif dan menjadi obat yang ampuh bagi mereka yang

\footnotetext{
${ }^{4}$ Kabar mengenai Hotel van Vogel yang pernah menyita perhatian muncul dalam pemberitaan tentang kunjungan Pangeran Kekaisaran Rusia, Nicholas Alexandrovich ke Garut pada bulan Maret 1891 bersama Pangeran George II, Putera Mahkota Kerajaan Yunani. Kedua pangeran tersebut menginap di rumah bupati Garut, sementara rombongan pengiringnya ditempatkan di Hotel van Vogel dan Hotel van Horck (Soerabaijasch Handelsblad, 16/03/1891).
} 
sedang menjalani proses pemulihan di hotel ini. Tidak pernah ada tamu yang merasa sungkan dengannya. Bahkan, ruangan pribadi Ny. Horck selalu dipenuhi para tamu yang sengaja datang untuk sekadar mengobrol dan menghabiskan waktu bersama." (Maurik, 1897: 194).

Periode kedua (1908-1941) perkembangan hotel di Garut ditandai dengan berdirinya hotel-hotel modern yang dikelola secara lebih profesional. Kemunculan hotel-hotel tersebut berkaitan dengan berkembangnya kegiatan pariwisata internasional yang dimulai pada akhir dekade 1900. Dalam tahun-tahun itu dorongan untuk mendatangkan wisatawan asing di kalangan penduduk koloni makin menguat. Hal tersebut ditengarai oleh tumbuhnya kesadaran tentang betapa besarnya potensi yang dimiliki Hindia serta keuntungan yang akan diperoleh dari adanya praktik ini. Terlebih, dari sisi aksesibilitas Hindia dinilai sangat siap karena sudah terhubung ke pelabuhanpelabuhan utama di Asia, Australia dan Eropa dengan kapal uap (Meuleundijks, 2017: 29).

Di lain pihak, pemerintah kolonial membutuhkan suntikan dana tambahan untuk membiayai program-program Politik Etis yang mulai bergulir pada 1901. Pariwisata internasional dipandang bisa menawarkan sumber pendapatan baru bagi ekonomi kolonial dengan biaya sosial atau infrastruktur yang relatif sedikit. ${ }^{5}$ Untuk maksud tersebut, Gubernur Jenderal J.B. van Heutsz menginisasi pembentukan biro pariwisata internasional pertama di Batavia bernama Vereeniging Toeristenverkeer (VTV) pada 1908 (Cribb, 1995: 195).Tujuan dibentuknya asosiasi ini adalah untuk mempromosikan Hindia Belanda kepada turis internasional. VTV menempatkan perwakilannya di sejumlah negara potensial, seperti di Belanda, Inggris, Jerman, Amerika Serikat, IndiaBritania, Ceylon, negara-negara Selat jajahan Inggris, Thailand, Filipina, Hong Kong, Cina, Australia, Jepang dan Hawaii (Sunjayadi, 2007: 37; Meulendijks, 2017: 31).

\footnotetext{
5 Salah satu sumber pembiayaan Politik Etis adalah melalui pembentukan Department van Gouvernementsbedrijven (Departemen Perusahaan Pemerintah) pada 1907. Departemen ini membahawahi perusahaan-perusahaan bidang transportasi, seperti Staatsspoor-en Tramwegen dan pos. Wajar apabila pariwisata sebagai sektor yang berhubungan dengan perjalanan menjadi salah satu sumber pemasukan dinas ini yang diharapkan dapat menyokong kelangsungan Politik Etis. Lihat V.J.H. Houben, 'Profit versus ethics: Gouvernment enterprises in the late colonial state' dalam Robert Cribb (ed), The Late Colonial State in Indonesia. Political and economic foundation of the Netherlands-Indies 1880-1942 (Leinden: KITLV Press, 1994).
} 
Garut yang sejak akhir abad ke-19 sudah ramai dikunjungi para pemukim Eropa di Hindia diprioritaskan menjadi daerah tujuan yang dipromosikan VTV. Di kawasan ini terdapat banyak objek wisata alam, mulai dari gunung, danau, kawah vulkanik, hingga sumber air panas. Semua objek tersebut relatif mudah diakses (Ponder, 1934: 242). Alasan lainnya pemerintah tidak perlu lagi menggelontorkan anggaran besar untuk mengembangkan pariwisata, mengingat di Garut, infrastruktur dan sumber daya pariwisata yang menjadi kebutuhan saat itu relatif telah tersedia. Pada tahun 1909 VTV memberikan bantuan dana sebesar 1.000 gulden kepada perwakilannya di Garut untuk menata fasilitas di sejumlah objek wisata, seperti pengadaan bangku di sekitar Kawah Papandayan, membangun gazebo-gazebo di kawah Talaga Bodas, serta pemasangan petunjuk arah menuju objek-objek wisata (Tweede Jaarverslag VTV, 1910: 8).

Dimasukannya Garut dalam agenda promosi VTV pada 1908 menandai dimulainya era pariwisata internasional di kawasan ini sekaligus melengkapi pariwisata domestik yang sudah berkembang sebelumnya. Semenjak itu Garut mulai dibanjiri arus wisatawan asing yang datang dari berbagai negara, terutama negara-negara Eropa, Amerika Utara, dan Australia. Sebagian wisatawan juga datang dari sejumlah negara di Asia, seperti Jepang, Hong Kong, Singapura, dan Thailand

Kondisi tersebut menuntut hotel-hotel di Garut untuk lebih meningkatkan profesionalitas dan kualitas pelayanannya. Berbeda dari hotel keluarga, hampir semua hotel yang beridiri pada periode kedua (1908-1942) berbentuk perusahaan atau perseroan terbatas (N.V). Di antara cirinya adalah terdapat struktur yang jelas, seperti komisaris, direktur, manajer, bendahara, dan staf hotel yang bekerja sesuai bidangnya. ${ }^{6}$ Pada periode ini juga hotel-hotel di Garut terbiasa mengembangkan jejaring melalui bentuk-bentuk kerja sama dan kolaborasi dengan berbagai pihak, seperti dengan organisasi kepariwisataan dan pihak-pihak swasta (Kelling, 1929: 748-749, 753).

\footnotetext{
${ }^{6}$ Hotel-hotel modern di Garut mulai benar-benar melakukan pembenahan struktur perusahaannya menjelang akhir Perang Dunia I, seperti Hotel Kurhaus pada 1917 (De Locomotif, 10/12/1918); Hotel Belvedere pada 1919 (Nieuws van Den Dag Voor Nederlandsch-Indië, 25/03/1919); Hotel Grand Ngamplang dan Hotel Grand Cisurupan pada 1920 (Kelling, 1929: 748-749; Dyck, 1922: 35).
} 
Hotel modern pertama yang berdiri di Garut adalah Villa Dolce yang mulai beroperasi tahun 1908 di dekat Stasiun Garut (5 menit berjalan kaki). ${ }^{7}$ Direktur sekaligus manajer hotel ini dijabat oleh L.W.H. Ingenhous, mantan kepala chef di 'Stam dan Weyns', sebuah perusahaan yang bergerak dalam bisnis restoran (Het nieuws van den dag voor Nederlandsch-Indië, 01/07/1911).

Lalu ada Hotel Papandayan yang mulai dibuka pada 1 Januari 1910 dengan mengambil alih kepemilikan Hotel Rupert. ${ }^{8}$ Direktur sekaligus manajer pertama hotel ini adalah H.A.C. Hacks, mantan koki pada sejumlah hotel di Den Haag dan Amsterdam (Couperus, 1923: 146). Namun, setelah bercerai dari istrinya pada 1923, kepemilikan Hotel Papandayan jatuh ketangan mantan istrinya, M.A. Petten, yang kemudian menggantikan posisi Hacks sebagai manajer (De Preanger Bode, 29/06/1923).

Berada tepat di seberang Hotel Papandayan terdapat Hotel Kurhaus yang mulai beroperasi pada 1912. Hotel ini sebelumnya merupakan Hotel van Horck yang dibeli oleh C.C. Mulie seharga 110.000 gulden. Hotel Kurhaus menjadi debut Mulie dalam dunia usahaakomodasi setelah iapensiun sebagai direktur grup restoran Grimm dan Co., Surabaya (De Express, 29/04/1912).

Setelah hotelnya dijual, Horck mencoba peruntungan dengan membangun Hotel Villa Pauline di Cisurupan, kaki Gunung Papandayan (4.200 kaki) pada tahun 1913. Namun bisnis baru yang dijalankan van Horck itu tidak berlangsung lama. Pada tahun 1920, Villa Pauline kembali dijual kepada Nederlansch-Indisch Hotelvereeniging (NIHV). ${ }^{9}$ Semenjak kepemilikannya beralih, hotel tersebut berganti nama menjadi Hotel Grand Cisurupan dengan W. Kooymans sebagai manajernya (Kelling, 1929: 748).

Pada waktu yang bersamaan NIHV juga membeli Hotel Sanatorium Ngamplang (3.100 kaki). Sebelumnya hotel ini merupakan milik Dr. Mulder, seorang pensiunan dokter di Garut. Ia mendirikan Hotel Sanatorium pada 1913 untuk tempat pemulihan kesehatan dan rumah peristirahatan. Namun, tak lama setelah hotel itu berdiri, justru

${ }^{7}$ Lokasi Hotel Villa Dolce berada di Jalan Melati, asrama Haji Kabupaten Garut sekarang (Anggadipradja, 1984:159).

${ }^{8}$ Berita tentang pembukaan Hotel Papandayan dimuat dalam Het nieuws van den dag voor NederlandschIndie, $1 / 12 / 1910$.

${ }^{9}$ Pada tahun 1930-an, NIHV berubah nama menjadi Netherland India Hotel Co. (Tourism Dutch East Indies, September-Oktober 1938). 
jumlah wisatawan yang mengunjungi tempat ini jauh lebih banyak ketimbang mereka yang melawat karena alasan kesehatan. Melihat potensi tersebut, pada tahun 1920 NIHV tertarik untuk membeli Sanatorium dari tangan Dr. Mulder untuk dikembangkan menjadi hotel modern (Dyck, 1922: 35-36). Semenjak beralih kepemilikan, hotel ini lalu berganti nama menjadi Hotel Grand Ngamplang dengan W. De Grooth sebagai manajernya (Het Hotelblaad, 1938).

Berada tak jauh dari lokasi Grand Hotel Ngamplang, terdapat Villa Hotel Belvedere yang mulai beroperasi pada $1919 .{ }^{10}$ Hotel ini berada di bawah naungan N.V. Villa Hotel Belvedere yang berkantor pusat di Bandung. Dana yang dihabiskan untuk membangun hotel ini mencapai 150.000 gulden. Gopner dan van Dompseler bertindak selaku komisaris utama hotel ini, sementara manejernya dijabat oleh Mr. Simon. (Nieuws van Den Dag Voor Nederlandsch-Indië, 25/03/1919).

Pada tahun 1926, H.A.C. Hacks, mantan manajer Hotel Papandayan mendirikan sebuah hotel baru bernama Radium 'Hacks' yang berlokasi di kawasan lereng Kawah Kamojang(4.500. Keberadaan hotel ini juga menandai kembalinya Hacks dalam dunia akomodasi setelah kasus perceraian dengan mantan istrinya (De Koerier, 29/12/1927). Lalu ada juga hotel-hotel lainnya yang lebih kecil, seperti Hotel Cilauteureun (Der Preanger) di pesisir pantai selatan (Pameumpeuk), Hotel van Hegel di Tarogong, dan Hotel Melayu (Anggadipradja, 1984: 167; Arismunandar, Dienaputra dan Mulyadi, 2020: 165).

\section{Strategi Hotel-hotel Pegunungan di Garut}

a. Menyiasati Tekanan Persaingan

Merebaknya investasi bidang akomodasi di Garut pada akhir periode kolonial diikuti pula dengan persaingan di antara para pelaku usaha sektor ini. Menjadi menarik karena pola persaingan yang terbentuk mengarah pada segmentasi pasar yang spesifik,

${ }^{10}$ Lokasi hotel Belvedere sekarang menjadi komplek asrama tetara di Sukadana, Garut (Anggadipradja, 1984: 167). 
yakni wisatawan. ${ }^{11}$ Hal tersebut menjadi tantangan tersendiri bagi para pengelola berghotel karena biasanya tamu-tamu mereka tinggal untuk jangka waktu yang relatif lama. Maka sudah sepatutnya merekamenyiapkan fasilitas dan pelayanan yang mampu membuattamu-tamunya selalu merasa senang dan nyaman agar mereka tidak mati kutu karena kebosanan.

M.A.J. Kelling mengatakan setidaknya ada delapan poin yang mesti dikuasai oleh seorang manajer berghotel. Pertama, ia harus memahami berbagai jenis olahraga, terutama tenis, golf, dan berkuda. Kedua, mampu merencanakan program tur/perjalanan yang dilakukan dari hotelnya dan merekomendasikan program tersebut sesuai kondisi fisik tamunya. Ketiga, mampu menyusun program tertentu untuk mengisi waktu para tamu selama mereka tinggal, sehingga mereka dapat melewati hari-harinya dengan senang hati. Keempat, ia mesti bijaksana dan penyabar. Kelima, mampu mengidentifikasi tamu mana yang kira-kira bisa dikumpulkan untuk memulai tur bersama dan bertindak menjadi penengah bila terjadi perselisihan. Keenam, mengingat labilnya iklim pegunungan, maka ia mesti pintar menjaga suasana hati tamu-tamunya. Ketujuh, salah satu cara menjaga suasana hati para tamu adalah denganmenyediakan makanan \& minuman yang sesuai dengan selera mereka. Kedelapan, pastikan tamu pulang dengan perasaan puas karena dengan begitu kemungkinan untuk mempromosikan hotel tempat mereka tinggal kepada kenalannya yang lain terbuka lebar (Kelling, 1929: 745).

Hal lain yang juga mesti dipahami bahwa pada dasarnya berbagai strategi yang diadopsi oleh para pelaku usaha akomodasi wisata bertujuan untuk meningkatkan kemampuan perusahaan agar mendapat keuntungan dari produksi jasa dan pengalaman pariwisata. Maka dari itu, menurut Shaw dan Williams hal terpenting yang mesti diperhatikan adalah sejauh mana mereka mampu mengubah paradigma persaingan

\footnotetext{
${ }^{11}$ Menurut laporan Tourism in Netherland India (Vol. IX No. 4, 1934) Garut disebut sebagai salah satu daerah yang menjadi pusat keberadaan hotel-hotel pegunungan berlabel 'tourist hotel' paling lengkap dan paling mewah di Jawa. Dalam terbitannya yang lain (Vol. VII No. 4, 1932) hotel-hotel di Garut masuk dalam jajaran "Good hotels has been established at the places throughout Java most attractive to visitors".
} 
melalui inovasi dalam hal teknologi, produk pelayanan (jasa) dan fasilitas (2004: 83$85)$.

Dari awal pengoperasiannya Hotel van Horck sudah berusaha menghadirkan akomodasi pegunungan yang ideal. Meski berada di bawah pengawasan keluarga, Horck berhasil mempelopori pengembangan konsep hotel yang memadukan unsur kesehatan dan kesenangan di Garut. Untuk membantu proses pemulihan kesehatan para tamunya, ia melengkapi setiap kamar dengan beranda pribadi yang menghadap langsung ke taman. Beranda tersebut berfungsi sebagai ruang duduk dengan seperangkat meja dan kursi untuk bersantai menikmati udara pegunungan sambil meminum teh, kopi atau menyantap kudapan (McMillan, 1914: 229). Ia juga melengkapi fasilitas hotelnya dengan kamar mandi air panas, ruang bilyar, ruang rekreasi, ruang baca/perpustakaan, kuda tunggangan, dan bar (Doorman dan Nieuwenkamp, 1898: 31).

Dari segi makanan, Horck memperkenalkan konsep perasmanan atau dikenal juga dengan istilah rijstaffel. Menurut Scidmore momen makan malam sering dimanfaatkan para tamu untuk berinteraksi satu sama lain selepas lelah beraktivitasseharian. Ia tak pernah merasa sendirian karena selalu ada teman yang menyenangkan untuk diajak mengobrol dalam bahasa Inggris. Mereka juga terlihat senang karena Ny. Horck menyajikan banyak sekali jenis makanan. Itu sebabnya hotel ini sangat terkenal dari ujung Anyer sampai Banyuwangi (1898: 277-278).

Horck tampaknya cukup jeli menangkap peluang bisnis dari ramainya lalu lintas wisatawan domestik. Ia menyadari jika para pengunjung yang mengarus ke Garut bukan hanya para pencari kesehatan saja, melainkan juga orang-orang yang memang sengaja datang untuk berlibur. Langkah ini menjadi poin plus bagi Horck ketika dua pesaingnya - Hotel Rupert dan Hotel van Vogel - masih menjalankan usaha hotelnya sebagai rumah pemulihan (sanatorium) paling tidak sampai tahun 1900(Doorman dan Nieuwenkamp, 1898: 33).

Terhubungnya Garut dengan jaringan pariwisata internasional pada akhir 1900an membuat intensifikasi persaingan antar-hotel makin kentara. Semenjak itu kawasan ini semakin diminati oleh para pelaku usaha perhotelan untuk merintis bisnis mereka. 
Bersamaan dengan itu bisnis akomodasi berbasis keluarga yang lama perlahan menghilang, digantikan hotel-hotel modern yang dikelola secara lebih profesional. Pada tahun 1910, Ny. Rupert menjual hotelnya kepada H.A.C. Hacks yang kemudian mendirikan Hotel Papandayan. Dua tahun berselang, giliran van Horck yang menjual hotelnya kepada C.C. Mulie. Keterbatasan modal, pengetahuan, dan ketidaksiapan merespon pola persaingan yang mulai bergeser pada industri skala besar disinyalir menjadi faktor yang menyebabkan kegagalan hotel-hotel keluarga di Garut dalam mempertahankan bisnisnya.

Beroperasinya Grand Hotel Villa Dolce pada 1908 menandai era baru duniaakomodasi di Garut. L.H.W. Ingenhous berhasil mengubah citra hotel pegunungan yang semula identik dengan hotel keluarga menjadi hotel modern kelas 1 yang sarat dengan kemewahan. Hotel ini memilki 36 kamar yang dilengkapi kamar mandi pribadi, keran air panas dan dingin, serta full-length bathtub. Dibangun pula sarana olah ragasebagai fasilitas yang dapat dimanfaatkan para tamu hotel secara gratis, seperti kolam renang dan lapangan tenis (Official Tourist Bureau, 1913: 52). Ingenhous juga sering mengundang kelompok musik tradisionaluntuk menghibur para tamunya, seperti para pemain angklung, calung, dan tarengkong. Biasanya pertunjukan tersebut berlangsung di taman hotel dari siang hingga sore (Tokugawa, 2006: 214).

Pada tahun 1911, Hotel Villa Dolce menerima banyak kritikan terkait masalah makanan. Para tamu yang merasa kecewa lalu melaporkan maslah ini kepada VTV. Mereka mengaku tidak pernah menikmati makanan yang layak selama tinggal di Villa Dolce. Makanan yang disajikan sering kali sudah dalam kondisi dingin serta pelayanannya kurang responsif. Untuk menindaklanjuti keluhan tersebut, VTV pun memutuskan untuk tidak lagi merekomendasikan Villa Dolce kepada para wisatawan. ${ }^{12}$ Tindakan VTV tersebut berdampak pada kunjungan tamu yang menginap di Villa Dolce.

\footnotetext{
${ }^{12}$ Ada enam laporan yang masuk kepada VTV dari turis asal Amerika, Inggris, Jerman, Prancis, dan Australia yang tidak disebutkan namanya. Keluhan mereka bernada sama, yakni soal makanan yang disajikan pihak hotel.
} 
Merasa dirugikan, L.H.W. Ingenhous lalu melayangkan surat protes yang ditujukan langsung kepada Gubernur Jenderal sebagai pihak yang ikut mengawasi aktivitas asosiasi tersebut. Ia mengungkapkan kekecewaan atas perlakuan VTV yang dianggap telah merugikan perusahaannya. Ia juga merasa sudah diperlakukan tidak adil karena VTV hanya merekomendasikan Hotel Papandayan saja, yang mana merupakan pesaingnya. Protes Ingenhous pun ditanggapi VTV melalui surat balasan dengan menyertakan lampiran berisi daftar laporan keluhan yang masuk. ${ }^{13}$

Persoalan makanan yang sempat merugikan perusahaannya itu menjadi titik balik bagi Villa Dolce untuk menata kembali strategi binisnya. Hal pertama yang dilakukan adalah memperbaiki sistem layanan dan mempekerjakan koki-koki profesional yang berada langsung di bawah pengawasan manajer. Untuk memulihkan kepercayaan publik terhadap hotelnya, identitas Ingenhous sebagai mantan chef di restoran 'Stam dan Weyns' selalu disertakan pada setiap laman promosi. Ingenhous tampaknya ingin menawarkan standar masakan Eropa sebagai produk unggulan di hotelnya alih-alih fasilitas dan kemewahan semata. Cara tersebut terbukti berhasil. Pada tahun 1923, The Goroet Express and Tourist Guide (12/01) menobatkan Villa Dolce sebagai hotel terbaik dalam kategori Europe Cuisine di Garut.Hotel ini juga menyandang julukan 'The Lido of the Preanger' dari majalah Tourism in Netherland Indiapada 1934.

Pesaing terdepan Villa Dolce adalah Hotel Papandayan. Hotel yang berdiri di atas lahan seluas enam hektar itu menjadi salah satu hotel modern kelas 1 terbesar di Jawa. Hotel Papandayan memiliki 100 kamar - 50 kamar sudah dilengkapi kamar mandi air panas dan full-length bathub. Hotel ini juga memiliki dua lapangan tenis berstandar yang sering digunakan untuk ajang kejuaraan 'Java Championship'. Dari segi makanan, Hotel Papandayan menyajikan menu masakan khas Eropa dan beragam jenis minuman beralkohol impor. Tarif kamar di hotel Papandayan berkisar antara 6-8 gulden per-hari (The Department of Railways Tokyo, 1920: 414; The Tourist Guide and Garoet Express, 7/04/1923).

\footnotetext{
${ }^{13}$ Korespondensi antara VTV dengan L.W.H. Ingenhous "Hotel Villa-Dolce" dalam Algemene Secretarie Grote Bundel TZG Agenda 1891-1942 No. 7915, Koleksi ANRI.
} 
H.A.C. Hacks menjadi sosok kunci di balik berbagai strategi yang dikembangkan oleh Hotel Papandayan. Hal pertama yang menjadi fokus perhatiannya adalah penataan masalah pelayanan. Pada tahapan tertentu ia tetap mempertahankan metode pelayanan yang diterapkan pada hotel-hotel keluarga dalam membangun relasi antara pihak pengelola dengan para tamunya. Ia kerap berperan sebagai 'ayah' atau 'paman' bagi para tamunya dan rutin melakukan kontak dengan mereka. Sikap Hacks yang hangat membuat para tamu merasa nyaman tinggal di hotelnya. Dengan sendirinya metode tersebut menjadi carapromosi yang efektif untuk menaikan reputasi Hotel Papandayan di mata wisatawan (Couperus1923: 142). Hal tersebut tercermin dari kesan yang diungkapkan oleh seseorang berinisial 'pt' yang pernah menginap di Papandayan.

"Pertengahan Agustus 25 tahun yang lalu saya memutuskan untuk menghabiskan 6 minggu masa cuti saya di Jawa. Dalam kesempatan itu, saya tinggal selama 1 minggu di Hotel Papandajan, Garoet. Pada momen itulah saya mengenal Tuan Hacks. Dia adalah sosok pria yang sangat gesit dan siap dimintai bantuan kapan saja. Sekalipun jabatannya tinggi, tapi dia bukanlah tipikal orang yang hanya bekerja di belakang meja. Setiap hari dari pagi hingga malam dia terlihat berkeliaran di hotelnya dan selalu ada untuk tamu-tamunya. Tak ada perasaan canggung di antara kami. Dia juga kerap bergabung bersama kami. . . . Tuan Hacks yang hangat sangat dekat dengan tamu-tamunya. Itulah sebabnya sampai sekarang saya merasa seperti mempunyai hubungan khusus dengannya. Mungkin tamu-tamu lain juga merasakan hal serupa." (Het Hotelblad, September 1937).

Untuk menarik minat calon konsumennya, Hotel Papandayan mengembangkan satu bidang usaha berupa program tur ke objek-objek wisata di Garut. Ada beberapa paket perjalanan yang ditawarkan, antara lain paket perjalanan ke Situ Cangkuang-Situ Bagendit-Cipanas; paket perjalanan ke Kawah Papandayan; paket perjalanan ke Kawah Talaga Bodas; paket perjalanan ke Kawah Kamojang; paket perjalanan ke Kawah Manuk, dan paket perjalanan ke Pantai Cilauteureun (Pameumpeuk). Selain itu, ada juga paket wisata berburu dan memancing di kawasan Garut selatan. Tarifuntuk masingmasing paket perjalanan berada dikisaran 30-50 gulden. Biaya tersebut sudah termasuk sewa mobil, sopir, pemandu, kuli (tandu dan barang), kuda, perahu, hiburan, sarapan, dan makan siang. Bagi tamu hotel yang mengikuti program tur mereka akan dibangunkan pagi hari dan disiapkan sarapan segera untuk kemudian memulai 
perjalanan. Mereka akan diantarkan ke tempat tujuan sesuai paket perjalanan yang dipesan dan kembali ke hotel pada siang atau sore hari (The Tourist Guide and Garoet Express, 8/12/1922; 22/12/1922; 12/01/1923).

Kehadiran Hotel Kurhaus yang mengambilalih kepemilikan Hotel van Horck pada tahun 1912 makin menambah ramai persaingan. C.C. Mulie selaku direktur dan manajer yang baru pelan-pelan mulai mengubah citra hotel keluarga yang sudah melekat di tangan pemilik sebelumnya menjadi hotel modern kelas 1. Bermodalkan dana 1.000 gulden, ia melakukan sejumlah perombakan baik dari segi fisik maupun manajerialnya. Langkah pertama yang dilakukan adalah menambah jumlah kamar yang semula 30 menjadi 50 kamar serta membangun fasilitas olahraga berupa lapangan tenis. Untuk menarik minat calon konsumennya, disediakan pula ruangan khusus untuk hiburan. Setiap malam di ruangan tersebut diselenggarakan orkes musik yang tampil secara reguler untuk menghibur para tamu hotel (De Express, 29/04/1912).

Usaha yang dirintis Mulie itu ternyata tak berjalan sesuai harapan. Meski telah melakukan beberapa perombakan, namun hal tersebut tidak terlalu banyak berpengaruh terhadap tingkat kunjungan. Hotel Kurhaus tampaknya masih kalah bersaing dari tetangganya, Hotel Papandayan. Pada 1917 Mulie memutuskan untuk menyewakan Hotel Kurhaus kepada L. Schliebner (De Locomotief, 18/10/1917; 10/12/1918). Di bawah manajemen barunya, Hotel Kurhaus membuka usaha penyewaan mobil yang bisa dimanfaatkan para tamunya untuk berkunjung ke objek-objek wisata. Schliebner juga melengkapi barnya dengan minuman beralkohol yang lebih beragam, mulai dari anggur Rhine dan Moselle, anggur Prancis, California, Australia, anggur merah dan putih (De Locomotief, 7/12/1918). Tarif hotel ini berkisar antara 6-8 gulden per-hari (The Department of Railways Tokyo, 1920: 414).

Setelah menjual hotelnya, Horck mendirikan hotel baru bernama Villa Pauline di Cisurupan. Pada awal kemunculannya, Villa Pauline cukup menyita perhatian karena menjadi hotel pertama yang dibangun di kaki gunung Papandayan. Waktu itu kawah Papandayan dikenal sebagai objek wisata paling popular di Garut, sehingga banyak kalangan menilai keputusan Horck tersebut tepat (Het nieuws van den dag, 21/01/1914).Konsep hotel yang diusung tak berbeda jauh dari hotel yang ia kelola 
sebelumnya, yaitu memadukan unsur kesehatan dan kesenangan. Hotel Villa Pauline memiliki delapan bangunan utama. Di halamannya terdapat taman yang luas dan dihiasi oleh berbagai jenis bunga. Selain itu disediakan pula beberapa kamar mandi yang dilengkapi dengan keran air panas (Official Tourist Bureau, 1913: 52).

Sekalipun fasilitas Villa Pauline terbilang lengkap dan berada di lokasi yang menjanjikan, bukan berarti menjadi jaminan untuk menarik lebih banyak wisatawan. Faktor aksesibilitas menjadi masalah yang masih belum bisa teratasi sepenuhnya. Jarak tempuh dari Kota Garut ke hotel ini sejauh $18 \mathrm{~km}$ atau sekitar 45 menit perjalanan mobil mengingat kawasan Cisurupan baru terhubung dengan jaringan kereta api pada 1930. Sementara sebagian besar wisatawan yang berkunjung ke Garut datang dengan menggunakan kereta api. Umumnya mereka lebih memilih tinggal di hotel-hotel yang berada di sekitar stasiun. Villa Pauline lebih sering dijadikan tempat persinggahan oleh para wisatawan yang hendak mengunjungi kawah Papandayan alih-alih tinggal untuk jangka waktu yang lama.Di sana wisatawan biasanya memesan jasa kuli, kuda, dan tandu untuk pergi ke Kawah Papandayan (Walcott, 1914: 250).

Horck akhirnya menjual Villa Pauline kepada Nederlandsch-Indisch Hotelvereeniging (NIHV) pada 1920. Asosiasi yang berdiri pada 1919 itu berambisi untuk mengelola jaringan hotel-hotel di Jawa, terutama di kota-kota yang menjadi tujuan wisata. Mereka memulai misinya itudengan mengelola empat hotel pegunungan. Dua di antaranya berada di Garut, yaitu Hotel Villa Pauline (Grand Hotel Cisurupan) dan Hotel Sanatorium (Grand Hotel Ngamplang). Sementara sisanya adalah Hotel Sanatorium Tosari dan Hotel Nongkojajar di Jawa Timur (Kelling, 1929: 748).

Berbeda dari para pesaing terdahulunya, NIHV mengembangkan dua hotelnya di Garut dengan mengusung konsep resort yang berorientasi pada pelayanan terpadu. Langkah pertama yang dilakukan adalah membenahi masalah kesehatan dan kebersihan. Kedua persoalan tersebut acap kali menyebabkan para wisatawan terkena disentri atau tifus alih-alih memulihkan kesehatan mereka di daerah pegunungan. NIVH berkonsultasi kepada sejumlah ahli hidrologi untuk memeriksa kelayakan sumber air minum dan menjalani pemeriksaan bakteriologis secara teratur. NIHV juga mempekerjakan dokter umum di Grand Hotel Ngamplang untuk merawat tamu-tamunya 
yang sakit. Dokter tersebut rutin mengunjungi Grand Hotel Cisurupan untuk melakukan pemeriksaan di sana (Kelling, 1929: 748-749).

Langkah selanjutnya adalah memoderniasasi jaringan transportasi guna mengatasi masalah aksesibilitas. Hal tersebut dinilai sangat penting karenakedua hotel NIHV di Garut berada jauh dari stasiun kereta api - Grand Hotel Ngamplang 7 km dan Grand Hotel Cisurupan $18 \mathrm{~km}$. Dimulai dengan memperbaiki akses jalan yang menghubungkan Ngamplang dan Cisurupan, termasuk memperbaiki beberapa jembatan yang rusak. Lalu mendirikan N.V. Nederlandsch-Indisch Automobielverhuurderij (N.V. NIA), sebuah unit usaha yang bergerak di bidang jasa transportasi. Ada dua bidang usaha yang dikelola unit ini, pertama adalah jasa penyewaan mobil untuk antar-jemput tamu di stasiun. Para tamu juga bisa menyewa mobil tersebut untuk mengantar mereka pergi mengunjungi objek-objek wisata (Kelling, 1929: 753). Kedua adalah jasa angkutan umum berupa omnibus yang beroperasi secara reguler dengan trayek Ngamplang-Garut (kota) - Cisurupan (Dyck, 1922: 63).

Untuk memenuhi pasokan bahan makan, Hotel Grand Ngamplang dan Grand Cisurupan mengembangkan peternakan sapi dan kebun sayur sendiri. Kedua hotel tersebut memiliki puluhan sapi perah yang ditempatkan di sebuah istal khusus. Para pegawai di istal merupakan orang-orang pribumi yang bekerja di bawah pengawasan langsung seorang mandor Eropa. Tugas mereka adalah memproduksi susu sapi segar untuk memenuhi kebutuhan konsumsi domestik hotel. Sisa susu yang tidak habis dikonsumsi ditampung pada sebuah tempat khusus untuk kemudian mereka olah menjadi mentega (Dyck, 1922: 39). Susu merupakan salah satu bahan makanan utama hotel-hotel di Garut. Biasanya dihidangkan saat sarapan bersama kopi, teh, coklat dan roti mentega atau selai (The Tourist Guide and Garoet Express, 22/12/1922).

Dari sisi fasilitas, baik Grand Ngamplang maupun Grand Cisurupan sudah dilengkapi dengan fasilitas modern yang terhitung mewah pada masanya. Keduanya dilengkapi dengan kolam renang, lapangan golf, tenis, lapangan berkuda, serta ruang bilyar (Het Hotelblad, 1938). Grand Cisurupan memiliki 45 kamar - 8 kamar dengan kamar mandi pribadi - dan tiga bangunan paviliun. Sedangkan Grand Ngamplang memiliki 42 kamar yang sudah dilengkapi dengan kamar mandi pribadi beserta keran air 
panas. Untuk memperlancar sirkulasi pengiriman surat dan barang, NIVH mendirikan kantor pos di Grand Hotel Ngamplang (Dyck, 1922: 36).

Pesaing terdekat Grand Ngamplang adalah Villa Hotel Belvedere yang juga menawarkan akomodasi penginapan kelas 1. Bila dibandingkan hotel-hotel lain di Garut, Villa Hotel Belvedere termasuk kecil, hanya memiliki 26 kamar (Nieuws van Den Dag Voor Nederlandsch-Indië, 25/03/1919). Walau begitu hotel ini memiliki fasilitas yang lumayan lengkap. Masing-masing kamar sudah dilengkapi kamar mandi pribadi dengan keran air panas. Kolam renang Villa Belvedere dikenal paling bagus di antara hotel-hotel lainnya. Tersedia pula lapangan tenis dan taman yang langsung mengarah pada lanskap pesawahan yang luas berlatar belakang pemandangan Gunung Cikuray (The Tourist Guide and Garoet Express, 16/03/1923).

Namun, pengelola Villa Hotel Belvedere rupanya perlu bekerja lebih keras untuk bisa bersaing mendapatkan banyak pengunjung. Sebagai pendatang baru mereka mesti berhadapan dengan hotel-hotel terdahulu yang telah mempunyai nama besar, seperti Hotel Papandayan dan Villa Dolce. Situasi tampak makin berat dirasakan ketika NIHV mengambil alih kepemilikan Sanatoriun Ngamplang pada 1920. Selain karena lokasinya berdekatan (sekitar $2 \mathrm{~km}$ ), pesaing barunya itu juga berani menawarkan tarif hotel dengan rentang harga yang sama, yakni 7-10 gulden per-hari dengan fasilitas yang relatif lebih lengkap. Dalam merespon hal tersebut, manajemen Villa Belvedere coba melakukan strategi pemotongan harga melalui program promosi, yakni memberikan tarif yang lebih murah bila tamu datang membawa serta teman hanya cukup membayar 14-18 gulden untuk dua orang (The Tourist Guide and Garoet Express, 16/02/1923).

Villa Belvedere mesti berjalan tertatih-tatih karena strategi pemotongan harga yang mereka tawarkan tampaknya tidak berdampak terlalu siginifikan. Dalam lima tahun pertama hotel ini berdiri tidak tampak adanya suatu inovasi yang berarti. Hal tersebut mengindikasikan ketidaksiapan dari para personalianya dalam menghadapi tekanan persaingan. Mereka justru malah terlilit masalah keuangan akibat sejumlah investor menarik kembali investasinya. Bahkan, pada tahun 1922 beredar kabar yang menyatakan bahwa Villa Belvedere tengah di ambang kebangkrutan (De Express, 22/07/1922). Sekalipun rumor ini ditampik dengan dalih sedang dalam proses evaluasi 
kinerja menyeluruh, namun pada akhirnya pihak manajemen tidak bisa lagi mengelak dari krisis keuangan yang berulang kali terjadi. Pada 1924 Villa Belvedere pun dijual kepada W. Schmauch (Het Nieuws van Den Dag Voor Nederlandsch-Indië, 22/07/1924; 15/09/1924).

Beralihnya kepemilikan tampaknya tak memberi dampak yang terlalu signifikan terhadap kemajuan perusahaan. Selama era W. Schmauch kebijakan yang paling terlihat dalam upaya menjaring lebih banyak pengunjung hanyalah kembali melakukan pemotongan tarif kamar untuk merespon persaingan harga dari kompetitor terdekatnya. Sayangnya kebijakan tersebut tidak banyak berpengaruh (Het Nieuws van Den Dag Voor Nederlandsch-Indië, 22/07/1924). Akhirnya pada 1931 pihak manajemen memutuskan untuk menutup Villa Belvedere (Nieuws van Den Dag Voor Nederlandsch-Indië, 9/07/1931).

Di lereng Kawah Kamojang, Hotel Radium 'Hacks' hadir menawarkan sebuah penginapan dengan mengusung konsep health resort. Kawasan kawah Kamojang yang berada di ketinggian 4.500 kaki menghasilkan udara segar yang cocok untuk pemulihan kesehatan. Di kawasan ini juga terdapat sumber air panas vulkanik yang berkhasiat untuk penyembuhan rematik dan penyakit kulit. Air tersebut dialirkan langsung ke hotel sehingga para tamu dapat memanfaatkannya untuk mandi (De Koerir, 29/12/1927).

H.A.C. Hacks mengembangkan Hotel Radium menjadi pusat spa medis di Garut. Mengingat waktu itu di Garut belum ada lagi hotel yang menyediakan fasilitas spa yang layak semenjak Hotel Rupert gulung tikar pada 1910. Ia membangun kamarkamar spa yang bisa digunakan oleh 1-2 orang lengkap dengan bak rendam air panas. Sumber uap yang digunakan berasal dari air panas alami dan hantaran asap gugusan kawah vulkanik kecil di sekitar hotel yang sudah melalui penyaringan sedemikian rupa. Menurut laporan Tourism In Netherlan India (1934) Hotel Radium 'Hacks' merupakan satu dari dua tempat spa medis terbaik di Jawa yang paling direkomendasikan kepada para wisatawan selain di Tosari (Jawa Timur).

Selain menawarkan penginapan, Radium 'Hacks' juga kerap kali dijadikan sebagai tempat peristirahatan oleh para wisatwan yang hendak mengunjungi Kawah Kamojang. Biasanya mobil-mobil yang mengantar para wisatawan diparkir di hotel ini. 
Di sana terdapat penyewaan kuda dan tandu yang bisa dimanfaatkan untuk mengantar mereka ke komplek kawah (De Indische Courant, 30/03/1936).

\section{b. Menjalin Kolaborasi}

Keberlangsungan hotel-hotel pegunungan di Garut sangat bergantung pada lalu lintas wisatawan. Semakin ramai kawasan ini dikunjungi oleh wisatawan, maka semakin besar pula kesempatan mereka memperoleh keuntungan. Oleh sebab itu para pelaku usaha perhotelan dituntut tidak hanya bertindak sebagai penyedia jasa akomodasi saja, tetapi juga terlibat aktif dalam menyokong upaya-upaya pemajuan pariwisata agar roda bisnis mereka dapat terus berputar. Langkah kongkret yang mereka tempuh adalah dengan melakukan berbagai bentuk kolaborasi dan aliansi dengan pihak-pihak yang mempunyai kepentingan yang sama. Selain dianggap penting bagi keberlangsungan perusahaan, pada saat itu kolaborasi dan aliansi juga mengarah pada kepentingan yang lebih luas dan substansial, yakni memelihara ekosistem industri perhotelan agar bisa terus bertahan (Het Hotelblaad, September 1937).

Upaya untuk mendatangkan wisatawan melalui praktik kolaborasi sudah coba dilakukan oleh para pelaku usaha perhotelan di Garut sejak akhir abad ke-19. Di antaranya adalah kolaborasi yang dilakukan oleh Hotel van Horck dan Hotel Homan (Bandung). Menjelang akhir abad ke-19, pergi ke daerah-daerah pegunungan telah menjadi rutinitas bagi sebagian pemukim Eropa di Hindia. Namun, pada saat itu informasi mengenai tempat-tempat menarik di daerah pegunungan masih sangat terbatas dan belum sepenuhnya tereksplorasi. Berangkat dari hal tersebut, Horck berinisiasi menjalin kolaborasi dengan Hotel Homan untuk menerbitkan sebuah buku panduan.

Dalam merealisasikan projek buku panduan tersebut, Horck dan Homan lalu menggandeng seorang penulis dan illustrator. Dia adalah J.G. Doorman, pengajar di Gymnasium Willem III, Meester Cornelis yang dipercaya untuk menyusun tulisannya. Sementara ilustarasinya dikerjakan oleh pelukis asal Haarlem, W.O.J. Nieuwenkamp (De Locomotief Samarangsch, 30/11/1898). Maka pada 1898, terbit buku berjudul Gids voor Bandoeng-Garoet en Omstreken. Buku ini berisi panduan perjalanan ke beberapa tempat menarik di Bandung dan Garut yang bisa dilakukan dari Hotel Homan dan Hotel 
van Horck. ${ }^{14}$ Di dalamnya disertakan pula biaya yang mesti dipersiapkan untuk mengunjungi setiap objek, mulai dari tarif kereta kuda, upah pemandu, kuli, tandu, dan harga sewa kuda tunggangan.

Setelah melewati tahun-tahun yang sulit, Hotel Kurhaus mulai membuka diri terhadap segala bentuk kolaborasi dalam upaya mendorong peningkatan jumlah pengunjung. Di bawah manajer barunya, L. Schliebner, mereka memutuskan untuk menjalin kerjasama dengan Java Motor Club (JMC), organisasi para pemilik kendaraan bermotor di Hindia Belanda. Schliebner menilai JMC adalah mitra yang paling tepat untuk diajak kerjasama. Selain aktif menyokong kegiatan pariwisata, organisasi ini juga mempunyai cabang di banyak kota sehingga akan sangat membantu perusahaan dalam meluaskan jejaringnya. Kerjasama antara Hotel Kurhaus dan JMC mulai berlaku pada tahun 1918. Sebagai konsesinya, Hotel Kurhaus akan memberikan harga khusus bagi setiap anggota JMC dan wisatawan yang memiliki kaitan dengan organisasi tersebut, termasuk membebaskan biaya parkir selama mereka tinggal (De Locomotief, 7/12/1918).

Perang Dunia I (PD I) yang berkecamuk di Eropa (1914-1918), tidak hanya berimbas terhadap penurunan tingkat kunjungan wisatawan asing ke Garut melainkan juga Hindia Belanda secara umum. Kelesuan tersebut telihat jelas dari laporan yang dirilis VTV pada 1921. Tingkat kunjungan wisatawan asing ke Hindia pada 1914 berjumlah 4.516 orang menurun drastis menjadi 380 orang pada tahun 1915. Meskipun pada tahun-tahun setelahnya mengalami kenaikan, namun itu tidak terlalu signifikan (1916 berjumlah 835 orang dan 1917 berjumlah 742 orang). Situasi dirasa mulai membaik menjelang akhir masa perang dengan tingkat kunjungan di atas seribu orang (1918 berjumlah 1.511 orang; th. 1919 berjumlah 2.296 orang; th. 1920 berjumlah 2.570 orang). ${ }^{15}$

\footnotetext{
${ }^{14}$ Objek wisata di Bandung yang ditawarkan dalam buku ini, antara lain Curug Panganten Dago, Kawah Tangkuban Parahu, Kawah Putih, dan Pangalengan. Sementara tempat-tempat menarik di Garut, seperti Cipanas, Gunung Guntur, Kawah Papandayan, Situ Bagendit, Situ Cangkuang, Kawah Manuk, dan Kawah Talaga Bodas.

${ }^{15}$ Lihat "Overzicht van het aantal vreemdelingen angekomen in den Nederlansch Indischen Archipel gedurende de jaren 1908-1920" dapat diakses di Algemene Secretarie Grote Bundel TZG Agenda 18911942 No. 7915, Koleksi ANRI.
} 
Meskipun jumlah kunjungan wisatawan asing ke Hindia secara umum berangsur meningkat, akan tetapi dampak dari PD I terhadap pariwisata di Garut tampaknya masih terus berlanjut hingga awal tahun $1922 .{ }^{16}$ Misalnya, Pemberita Makassar (17/11/1922) menyoroti kondisi pariwisata di Garut yang belum dapat pulih sepenuhnya. Disebutkan dalam laporannya bahwa krisis ekonomi yang terjadi pasca perang membuat Garut sepi dari kunjungan wisatawan asing. Situasi tersebut berimbas pada hotel-hotel di sana yang terus mengalami penurunan jumlah pengunjung.

Kelesuan yang melanda pariwisata Garut disadari betul oleh pihak-pihak yang berkepentingan dalam sektor ini, terutama para pelaku usaha akomodasi dan bahkan oleh VTV sendiri. Dorongan untuk menyiasati situasi tersebut kemudian muncul melalui upaya penataan kembali aspek pelayanan dan peningkatan aktivitas promosi. Pada awal tahun 1920-an, NIHV mendirikan Touristen-Bureau (biro pariwisata) yang pimpin langsung oleh W. De Grooth (Grand Ngamplang) dan W. Kooymans (Grand Cisurupan). Biro yang berlokasi di Stationweg itu disediakan khusus sebagai pusat informasi dan pelayanan bagi para wisatawan (Dyck, 1922: i, 53).

NIHV juga mengalihkan sasaran promosinya kepada wisatawan asal Belanda dan wisatawan domestik (penduduk Belanda di Hindia). Berdasarkan laporan VTV kunjungan turis asal Belanda selama periode 1919-1929 hanya berjumlah 2.140 orang. Jumlah ini masih kalah jauh di bawah wisatawan asal Inggris (12.323 orang) dan Amerika (8.876 orang). ${ }^{17}$ NIHV lalu bekerja sama dengan J.Z. Van Dyck untuk menyusun sebuah buku panduan. Tujuannya adalah untuk memperkenalkan keindahan alam Garut terutama kepada wisatawan berbahasa Belanda, baik di dalam maupun luar negeri yang belum pernah mengunjungi tempat ini. Maka pada 1922 terbitlah buku Garoet en Omstreken.

Pada tahun yang sama, VTV perwakilan Garut menerbitkan majalah mingguan (weekblad) berbahasa Inggris dan Belanda, The Tourist Guide and Garoet

\footnotetext{
${ }^{16}$ Dalam laporan tahunan VTV ke 15 disebutkan bahwa di antara daerah-daerah tujuan wisata yang mengalami penurunan pengunjung adalah Garut dan Sukabumi. Lihat Vijftiende Jaarverslag der Vereeniging Toeristenverkeer 1922, 1923, hlm. 4.

${ }^{17}$ Jaarverslag Vereeniging Toeristenverkeer 1922-1929.
} 
Express(TGGE). ${ }^{18}$ VTV menggandeng para pelaku usaha perhotelan di Garut untuk bekerja sama dalam mengembangkan majalah ini. Nama-nama seperti H.A.C. Hacks (Hotel Papandayan), L.W.H. Ingenhous (Hotel Villa Dolce), W. Kooymans (Grand Cisurupan), W. De Grooth (Grand Ngamplang), dan Simon (Villa Hotel Belvedere) aktif menyokong pada setiap penerbitan TGGE melalui pemasangan iklan hotel-hotel mereka.

Beberapa hotel di Garut juga coba meluaskan jejaringnya dengan bergabung bersama Algemeene Bond Hotelhouders in Nederland-Indie 'Ikatan para pemilik hotel di Hindia Belanda' (AHBINI). ABHINI terbentuk pada tahun 1925 di Grand Hotel Yogyakarta. Tujuan didirikannya perhimpunan ini adalah meningkatkan industri perhotelan dalam arti yang seluasnya, selain mempromosikan kepentingan material para anggota dan pegawai mereka. Untuk mencapai tujuan tersebut salah satu upayanya adalah mempromosikan pariwisata dalam arti yang luas (Sunjayadi, 2019: 152-153).

Anggota ABHINI tersebar hampir di seluruh kota di Hindia Belanda. Untuk memudahkan koordinasi antar-anggotanya perhimpunan ini membentuk semacam rayon kerja daerahyang disebut kring. Salah satunya adalah Kring Bandung yang membawahi hotel-hotel di Priangan dan Cirebon, termasuk Garut. Beberapa pelaku usaha perhotelan di Garut yang ikut bergabung dengan ABHINI, antara lain L.W.H Ingenhous (Villa Dolce), M.A. Petten (Hotel Papandayan), H.A.C. Hacks (Hotel Radium), dan W. Kooymans (Grand Hotel Cisurupan/NIHV) (Het Hotelblad, Desember 1937). ABHINI Kring Bandung rutin mengadakan pertemuan untuk membicarakan masalah-masalah yang berkaitan dengan bisnis perhotelan dan pariwisata. ${ }^{19}$

\footnotetext{
${ }^{18}$ TGGE menjadi terbitan berkala pertama yang menyajikan informasi mengenai pariwisata Garut secara komperhensif. Setiap minggunya VTV mendistribusikan majalah ini ke hotel-hotel kelas 1 di Hindia Belanda, Singapura, Malaysia, Siam, Hong Kong, Shanghai, India-Inggris, Australia dan sejumlah negara di Eropa. Tamu di hotel-hotel tersebut bisa memperoleh majalah ini secara gratis. Untuk menjaring calon wisatawan asal Amerika Serikat, VTV juga membuka agen pemasaran TGGEdi West-Street, New York City.

19 Contohnya membahas perkembanga terkini mengenai kondisi bisnis perhotelan di setiap daerah, mengkaji peluang yang bisa dimaksimalkan oleh hotel-hotel dalam menyambut musim liburan atau acaraacara sejumlah institusi yang mendatangkan peserta dari berbagai negara, seperti kongres kesehatan dan kongres ilmu pengetahuan. Lihat Het Hotelblad, April 1937.
} 
Pada 14 Februari 1934 diadakan rapat pembentukan Vereeniging Mooi Garoet (Asosiasi Garut Indah) yang dihadiri oleh Asisten Residen Sangster dan Bupati Garut Rd. Tg. M. Soeria-Kartalegawa sebagai penggagas. Tujuan dibentuknya asosiasi ini adalah de behartiging der Garoetsche belangan 'representasi dari kepentingan Garut'. Untuk mencapai tujuan itu, dilakukan berbagai upaya, antara lain mempromosikan wilayah Garut sebagai tempat tinggal yang nyaman dan daerah pariwisata (Sunjayadi, 2019: 166). Sebagai bentuk dukungan terhadap Mooi Garoet, ABHINI Garut menempatkan seorang perwakilannya dalam kepengurusan perhimpunan ini, yakni W. Kooymans dari Grand Hotel Cisurupan (Het Hotelblad, April 1937).

Selang beberapa waktu setelah resmi terbentuk,Mooi Garoet mengajak serta para pemilik hotel di Garut untuk menjalin kerja sama dengan VTV membicarakan masalah promosi. Kerja sama tersebut menghasilkan penerbitan nomor khusus Garut untuk majalah VTV, Tourism in Netherlands India pada $1934 .{ }^{20}$ Dari 57 foto yang digunakan sebagai ilustrasi majalah, 47 foto merupakan foto berobjek Garut dan sekitarnya. Misalnya foto Mesjid Garut, taman Hotel Villa Dolce, pasangan pengantin Sunda, Grand Hotel Ngamplang, perebunan teh beserta aktivitas para pekerjanya, dan Kawah Papandayan. ${ }^{21}$

Kedatangan Jepang pada pertengahan bulan Maret 1942 ke kota Garut menandai akhir kegiatan pariwisata di kawasan ini. PasukanJepang mengambil alih semua fasilitas umum yang ada di Garut, termasuk hotel-hotel. Hotel Papandayan ditutup untuk umum karena telah digunakan menjadi markas Kempetai dan para perwira tentara Jepang. Begitupun Hotel Ngamplang yang dimanfaatkan sebagai tempat kediaman orang-orang sipil Jepang. Tempat lainnya adalah Societeit Intra Montes yang dipakai asrama para prajurit. Lalu komplek pemandian air panas di Cipanas untuk tempat peristirahatan atau mewarat pasukan yang sakit (Sofianto, 1997: 113).

\footnotetext{
${ }^{20}$ Nomor khusus Garut ini dimuat dalam majalah Tourism in Netherlands India Volume IX No. 4 tahun 1934.

${ }^{21}$ Lihat juga “Mooi Garoet” dalam Het Vaderland staat- en letterkunding neuwsblad, 30 Oktober 1934.
} 


\section{PENUTUP}

Berbagai strategi yang dilakukan hotel-hotel pegunungan (berghotel) di Garut menandakan bahwa sektor akomodasi pariwisata kolonial bukan semata hadir sebagai sarana pelengkap untuk memfasilitasi kebutuhan para wisatawan. Hotel-hotel tersebut justru tampil menjadi sebuah entitas yang juga ikut berkepentingan dalam praktik pariwisata yang berlangsung. Mereka saling bersaing berebut atensi dari para wisatawan selaku target pasar mereka dengan menunjukan kelebihanan masing-masing.

Dalam menyiasati tekanan persaingan, hotel-hotel pegunungan di Garut mengembangkan berbagai inovasi yang berorientasi pada produk jasa dan pengalaman pariwisata. Upaya yang dilakukan adalah dengan menawarkan pengalaman masa tinggal yang nyaman dan menyenangkan melalui penyediaan macam-macam fasilitas dan pelayanan. Tak ayal mereka berlomba-lomba untuk melengkapi hotel-hotelnya dengan fasilitas modern, mulai dari kolam renang, lapangan tenis, golf, kamar mandi yang dilengkapi keran air panas dan dingin, ruang baca, hotel orkestra, hingga bar yang menyediakan beragam minuman beralkohol impor. Sedangkan dari sisi jasa atau pelayanan, mereka mengembangkan beragam macam penawaran, seperti sewa mobil, program tur, jasa omnibus, dan lain sebagainya.

Hotel-hotel pegunungan di Garut juga terbiasa mengembangkan jejaring melalui bentuk-bentuk kolaborasi dan aliansi dengan berbagai pihak. Hal itu dilakukan untuk menarik lebih banyak wisatawan datang agar roda bisnis mereka dapat terus berputar. Langkah-langkah yang mereka tempuh, antara lain dengan terlibat aktif dalam sejumlah asosiasi atau perhimpunan, menjalin kerja sama dengan sebuah organisasi yang terkait dengan pariwisata dan perjalanan, berkolaborasi dalam urusan promosi dengan para penyusun buku panduan dan media cetak, serta menyelenggarakan kegiatan bersama. 


\section{DAFTAR PUSTAKA}

Anggadipradja. 1984. Sejarah Garut dari Masa ke Masa. Garut: Pemerintah Daerah Tk. II Kab. Garut.

Bataviaasch Nieuwsblad, 12 Agustus 1890; 7 Juli 1896; 26 Juni 1923.

Buys, M. 1891. Batavia, Buitenzorg, en De Preanger, Gids voor bezoekers en toeristen. Batavia: G. Kolff \& Co.

Cooper, C. P. 1998. Tourism: Principles and Practice (2nd ed). London: Prentice Hall.

Couperus, L. 1992. Ootswaarts. Amsterdam: L.J Veen.

Cribb, R. 1995. "International turism in Java 1900-1930". Jurnal South East Asia Research, 3 (2), hlm. 193-204.

De Expres, 22 Juli 1922.

De Indische Courant, 30 Maret 1936.

De Koerier, 29 Desember 1927.

De Locomotief, 30 November 1898; 7 Desember 1918; 10 Desember 1918.

De Maasbode, 21 Juni 1923; 22 Juni 1923.

De Preanger Bode, 29 Juni 1923.

De-Lilah. 1899. Mevrow Klausine Klobben op Java. Utrecht: H. Honig.

De Wit, A. 1898. Facts and Fancies about Java. Singapura: Straits Times Press.

Doorman, J.G. \& Nieuwenkamp, W.O.J. 1898. Gids voor Bandoeng Garoet en Omstreken. Hotel Homan en Hotel van Horck te Bandoeng en Garoet.

Dyck, J.Z. 1922. Garoet en omstreken zwerftochten door de Preanger. Batavia: G. Kolff \& Co.

Furnivall, J.S. 2009. Hindia Belanda Studi Tentang Ekomoni Majemuk. Jakarta: Freedom Institute.

Gelder, W. 1889. Beschijving van het Eiland Java en Zijn Bewoners. Dell II: West Java. Batavia: G. Kolf. 
Gottschalk, L. 2008. Mengerti Sejarah. Jakarta: UI-Press.

Hardjasaputra, A.S. 2001. "Pariwisata di Bandung Tempo Dulu (1870-1940)". Makalah di Fakultas Sastra Universitas Padjadjaran Bandung.

Het Hotelblaad, April 1937; September 1937; Desember 1937; Maret 1938.

Het nieuws van den dag voor Nederlandsch-Indie, 1 Desember 1910; 25 Maret 1919; 22 Juli 1922; 21 Juli 1928; 9 Juli 1931.

“Hotel Villa Dolce” dalam Algemene Secretarie Grote Bundel TZG Agenda 1891-1942 No. 7915, Koleksi ANRI.

Houben, V.J.H. 1994. 'Profit versus ethics: Gouvernment enterprises in the late colonial state' dalam Cribb, R (ed), The Late Colonial State in Indonesia. Political and economic foundation of the Netherlands-Indies 1880-1942. Leiden: KITLV Press.

Jafari, J. 2000. Encyclopedia of Tourism. New York: Routledge.

Kelling, M.A.J. 1929. "Het Hotelwezen in Nederlands-Indie" dalam Indische Gids. Amsterdam: J.H. Bussy.

Maurik, J. 1897. Indrukken van een Totok. Amsterdam: van Holkema \& Warendorf.

McMillan, M. 1914. A Journey to Java. London: Holden \& Hardingham Adelphi.

Miller, C.J. 1908. The Newest Way Round the World. New York: Calkis and Company.

Meulendijks, H. 2017. Tourism and Imperialism in the Dutch East Indies: Guidebooks of the Vereeniging Toeristenverkeer in the Late Colonial Era (1908-1939). Tesis Tidak Diterbitkan. Utrecht: Utrecht University.

Mulyana, A. 2005. Melintasi pegunungan, pedataran, dan rawa-rawa; pembangunan jalur kereta api di Priangan 1878-1924. Disertasi Tidak Diterbitkan. Depok: Universitas Indonesia.

Munandar, A, Dienaputra, R.D, \& Mulyadi, R.M. 2020. "Dari Pasanggrahan hingga Grand Hotel: Akomodasi Penginapan untuk Turis pada Masa Hindia Belanda di Priangan (1869-1942)”, dalam Jurnal Patanjala, 12 (2). hlm. 159-176.

Oemar, F. 1896. "Een reisje in het oosten der Preanger-Regentschappen", dalam De Java Bode. 24 Maret 1896. 
"Overzicht van het aantal vreemdelingen aangekomen in den Nederlansch Indischen Archipel gedurende de jaren 1908-1920”. (1921). Diakses di Algemene Secretarie Grote Bundel TZG Agenda 1891-1942 No. 7915, Koleksi ANRI.

Ponder, H.W. 1934. Javanese Panorama. London: Seeley, Service \& Co. Ltd.

Provinciale Noordbrabantsche en 's Hertogenbossche courant, 12 Juni 1896.

Scidmore, E.R. 1898. Java the Garden of the East. New York: The Century Co.

Shaw, G \& Williams, A. 2004. Tourism and Tourism Spaces. London: Sage Publications.

Sjamsuddin, H. 2012. Metodologi sejarah. Yogyakarta: Ombak.

Soerabaijasch Handelsblad, 16 Maret 1891.

Sofianto, K. 1997. Kehidupan masyarakat Kota Garut 1930-1965. (Tesis). Program Studi Ilmu Sejarah, Program Pasca Sarjana FIB Universitas Indonesia, Depok.

Spencer, J.E. \& Thomas, W.L. 1948. "The Hill Stations and Summer Resort of the Orient”, dalam Geographical Review, Vol. 38, No. 4. Oktober 1948, hal. 637651.

Sunjayadi, A. 2007. Vereeniging Toeristen Verkeer Batavia (1908-1942) awal turisme modern di Hindia Belanda. Depok: FIB-UI.

Sunjayadi, A. 2018. "Pelayan Pribumi dalam Akomodasi Turisme di Hindia Belanda", dalam Jurnal Sejarah Abad. Vol. 2, No. 1. Juli 2018, hlm. 145-162.

Sunjayadi, A. 2019. Pariwisata di Hindia Belanda 1891-1942. Jakarta: KPG.

The Tourist Guide and Garoet Express, 8 Desember 1922; 22 Desember 1922; 12 Januari 1923; 2 Februari 1923; 16 Maret 1923; 7 April 1923.

Tokugawa, M. 2006. Perdjalanan menoedjoe Djawa. Bandung: Penerbit ITB.

Tourism Dutch East Indies, September-Oktober 1938.

Tourism In Netherlan India, Vol. VII No. 4. Juli-Agustus 1932; Vol. IX No. 4, 1934.

Walcott, A.S. 1914. Java and Her Neighbours: A Travellers Notes in Java, Celebes, the Moluccas and Sumatra. New York and London: G.P. Putnam's Sons. 
Withington, W.A. 1961. "Upland Resorts and Tourism in Indonesia: Some Recent Trends". Geographical Review, 51 (3), hlm. 418-423.

Withington, W.A.. 1910. Tweede Jaarverslag Vereeniging Toeristenverkeer 1909. Batavia: Javasche Boekhandel \& Drukkerij.

Withington, W.A. 1910. Java the wonderland. Batavia: Official Tourist Bureau.

Withington, W.A. 1920. An Official Guide to Eastern Asia Trans-continental Connections between Europe-Asia:East Indies. Tokyo: The Departement of Railways.

Withington, W.A. 1913. Illustrated tourist guide to Buitenzorg, the Preanger, and Central Java. Batavia: Official Tourist Bureau.

Withington, W.A. 1923. Vijftiende Jaarverslag der Vereeniging Toeristenverkeer 1922. Weltevreden: G. Kolf \& Co. 